\title{
Regimes Theory' as an Approach to Understanding Educational Cooperation in CARICOM and Commonwealth Countries
}

Tavis D. Jules

Loyola University Chicago, tjules@luc.edu

Follow this and additional works at: https://ecommons.luc.edu/education_facpubs

Part of the Education Commons

\section{Author Manuscript}

This is a pre-publication author manuscript of the final, published article.

\section{Recommended Citation}

Jules, Tavis D.. Regimes Theory' as an Approach to Understanding Educational Cooperation in CARICOM and Commonwealth Countries. Round Table: The Commonwealth Journal of International Relations, 108, : 435-446, 2019. Retrieved from Loyola eCommons, Education: School of Education Faculty Publications and Other Works, http://dx.doi.org/https://doi.org/10.1080/00358533.2019.1634886

This Article is brought to you for free and open access by the Faculty Publications and Other Works by Department at Loyola eCommons. It has been accepted for inclusion in Education: School of Education Faculty Publications and Other Works by an authorized administrator of Loyola eCommons. For more information, please contact ecommons@luc.edu.

\section{cc) (†) $\ominus$}

This work is licensed under a Creative Commons Attribution-Noncommercial-No Derivative Works 3.0 License. (C) Taylor and Francis, 2019. 


\title{
'Regimes Theory' as an Approach to Understanding Educational Cooperation in CARICOM and Commonwealth Countries
}

Tavis D. Jules

Cultural and Educational Policy Studies, Loyola University Chicago, Chicago, IL, USA

\begin{abstract}
This article discusses the implication of soft diplomacy in education, in the form of educational cooperation, for the governance of regimes. In drawing upon regime theory, it suggests that the Commonwealth should be viewed as a regime, and its survival is partly dependent upon how it uses educational cooperation to coordinate its functional areas, such as education. Moreover, educational cooperation at the transnational level is different from traditional South-South cooperation in that it is based on the coordination of hierarchic mechanisms. In drawing lessons from the experiences of the Caribbean Community (CARICOM) project and extending them to the Commonwealth project, it argues that soft diplomacy, around perceived global norms, propels national educational agenda-setting attitudes. From this it follows that educational cooperation is the new order of things in an era defined by educational multistakeholderism where new regimes and institutions arise and coexist alongside other regimes. In other words, the Commonwealth must now retool itself in an era driven by regime complex(es) where it must coexist and compete with issue-specific regimes as well as complex entities which are comprised of more than one regime.
\end{abstract}

KEYWORDS Regimes; educational cooperation; CARICOM; Commonwealth; educational diplomacy; multistakeholderism

CONTACT tjules@luc.edu

I'm grateful for the research support provided by Scott McGallagher in compiling this article. 


\section{Introduction}

Educational cooperation as a novel idea is gaining increased traction to explain the constructive use of soft power or soft diplomacy to enhance transnational educational endeavours across countries and 'trans-regional educational regimes' (Jules, 2018) in the Global South. Soft power (see Nye, 2004) in education is viewed as the 'nexus of influences in world affairs that relate to culture, science, technology, and other subtle forces' (Altbach and McGill Peterson, 2008, p. 314). Education cooperation, should not be viewed as the 'trading of support (if you back me in this, I'll back you) ... nor as some predetermined plan' but instead be perceived as operating 'jointly towards a common end' (Peard, 1951, p. 11). In this way, cooperative endeavours use soft diplomacy or aspects of 'educational diplomacy' (Jules, 2016) which are derived as an alternative to militaristic undertakings across functional areas (health, education, trans- portation, and security) to find a common path. Educational diplomacy speaks to 'norm-setting within international educational politics in the form of government-to- government' (Jules, 2016, p. 22) exchanges which are part of the new pluri-scalar order of things in an era of enhanced regionalism. In other words, educational diplomacy entails three broad aspects in that (i) it has a normative dimension; (ii) its activities include various issue areas, policy fields and types of diplomatic engagement; and (iii) it is a multi-level activity (Hone, 2014; Jules, 2016). Unlike educational diplomacy, which has developed as a bilateral policy mechanism, Peard (1951) perceptively suggests, inclusion of ' $c o$ ' as the first two letters of the word 'cooperation' implies working with, and therefore cooperation in education is about states working with each other to find commonality around perceived regional and global norms in the interstate system. This implies that educational cooperation is multilateral or trans-regional in scope, multi-level, and pluri-scalar.

Moreover, educational cooperation, at the transnational level is different from traditional South-South cooperation in that in education cooperation is based on the 'coordination of coordination' (Dale, 2005) of hierarchic mechanisms or what has been called 'meta-steering.' While South-South cooperation in education is premised upon cross-border activities through technical activities and educational exchanges (Chisholm, 2009; Morais Silva, 2009; Jules, 2016), some have suggested that international cooperation in education is based on the deepening of relationships between emerging and frontier markets and industrialised countries and takes the form of (i) the institutions and architecture of international organisations; (ii) development assistance, which is closely related; and (iii) international agreements to promote education and other development goals' (Williams, 2017, p. 1). In this way, educational cooperation, 'in the broadest sense occurs whenever two or more parties work together to achieve an educational objective' (McKenzie et al., 2008, p. 25) that may include exchanges, trade in services, and development assistance. However, this paper suggests that like educational diplomacy, educational cooperation is propelled by the non- economic processes of transnationalism and regionalisation - the coordination of external and internal mechanisms and governance activities - which have arisen as exogenous and endogenous actors become intertwined in the regulation and coordination of education (Jules, 2016). This is particularly relevant to educational cooperation between small states and the larger industrialised countries given the limitations of small states resulting from economies of scale. Thus, education cooperation has become synonymous with the building and deepening of alliances and partnerships around issue-specific areas (World Declaration on Education for All or Dakar Framework for Action) to shape educational policy dialogue.

As such, this paper uses regime theory as a conceptual scaffolding to explore the rise of education cooperation by comparing and contrasting different theoretical constructs of the cooperative endeavours and relationships within and between CARICOM and Commonwealth countries. While the English-speaking Caribbean Community (CARICOM) countries are a sub-grouping within Commonwealth countries, regime theory is used to explore how soft diplomacy, around perceived global norms, propels national educational agenda-setting attitudes. In other words, education cooperation between CARICOM countries is used as an illustration to tease out the implications for the Commonwealth project and approaches to cooperation in education among its member states. In the next section, regime theory is discussed with the implication that the behaviour of state-driven supranational entities warrants this designation. The following section uses CARICOM to explore the changing geometries and trajectories of cooperation in education as new actors enter hemispheric relations. The final section concludes with lessons from CARICOM's experience for the Commonwealth project by suggesting that it should move towards a deeper form of strategic cooperation. 


\section{(Re)Framing Cooperative Bureaucratic Practices in Education}

In today's world of excessively interconnected market economies where the economic processes of globalisation have 'paused' and there is a retreat towards regional trading agreements (RTAs), and with the dawning of the so-called fourth industrial revolution - which blends the physical with the cyber-physical - regime theory presents an emerging conceptualisation for recategorising state-driven bureaucracies at the supranational level. Regime theory provides a useful conceptual framework for illuminating the various processes in educational developments that are occurring at the trans-national level and driven by economic transnationalism within CARICOM and by extension, the Commonwealth. Stephen Krasner (1983) initially conceptualised a regime as a set of 'principles, norms, rules, and decision-making procedures around which actors' expectations converge in a given issue area' (p. 1). In this way:

Principles are beliefs of fact, causation, and rectitude. Norms are standards of behaviour defined in terms of rights and obligations. Rules are specific prescriptions or prescriptions for actions. Decision-making procedures are prevailing practices for making and imple- menting collective choice. (Krasner, 1983, p. 2)

Krasner (1982), recognising the continued disparities that exist between large and small states, suggests that economic well-being and political control in developing markets can be changed by amending the ' ... principles, norms, rules, and procedures that affect the movement of goods and factors in the world economy,' (p. 119). Krasner (1981) further suggests four conditions that have driven emerging markets to transform international regimes:

... the international weakness of virtually all developing countries; the domestic weakness of virtually all developing countries; the systemic opportunities offered by the international institutions which were created by a hegemonic power now in decline; and the pervasive acceptance of a belief system embodying a dependency orientation. (p. 120)

The changing dynamics of political projects, such as the Commonwealth, are in danger of becoming obsolete as new non-state actors emerge. While several studies (Stein, 1982; Krasner, 1983; Puchala and Hopkins, 1983; Haas, 1993) have conceptualised regimes as social institutions that display the "conjunction of convergent expectations and patterns of behaviour and practice' (Young, 1983, p. 94) they have not focused on projects, such as the Commonwealth. These two core elements of regimes, behaviour and practice, need not crystallise simultaneously. Thus, all regimes like CARICOM and by extension the Commonwealth, incorporate arrays of social conventions that emphasize their nature as human artefacts, having no existence or meaning apart from the behaviour of individuals or groups of human beings (Young, 1983). As social institutions, regimes constitute behavioural conventions that represent a response to coordinated problems and situations, in which the pursuit of interest leads to socially describable outcomes. Regimes are constituted when 'patterned state behaviour results from joint rather than independent decision-making' (Stein, 1982, p. 117). Thus, regimes arise because actors relinquish independent decision making in dealing with shared interests.

Keohane (1983) distinguishes between agreements and regimes, suggesting that agreements are ad hoc 'oneshot' arrangements, whereas the purpose of regimes is to facilitate agreements. Likewise, Jervis (1993) notes that regimes '[imply] not only norms and expectations that facilitate cooperation, but a form of cooperation that is more than the following of short-run self-interest' (p. 173). However, given CARICOM's and the Commonwealth's geographical character during their respective periods of regime configuration, they assumed a life of their own, each based upon the desires of its members. Since regimes do not arise of their own accord, they can be envisaged as 'intervening variables standing between basic and causal variables and outcomes of behaviour' (Krasner, 1983, p. 1). In this way, regimes transcend agreements.

Keohane (1984) notes that regimes are like contracts because they 'involve actors with long-term objectives who seek to structure their relationships in stable and mutually beneficial ways' (p. 146). Thus, regimes establish frameworks (reducing transactional costs), and coordinate actors' expectations (improving quality and quantity of information available to states) as issues arise within any given policy space. Keohane (1984) suggests that the 'denser the policy space [stemming from the legacies of colonialism], the more highly interdependent are different issues, and therefore the agreements made about them' (pp. 155-56). Concerning transactional costs, the optimal size of regimes will increase if the returns are high. In other words, if the price is higher to make separate agreements in dense policy spaces, then belonging to a regime becomes cost-effective for the states. In this way, regimes are designed to mitigate the effects of the international environment upon individual states. 
Thus, regimes are 'arrangements peculiar to substantive issue-areas in international relations that are characterized by the condition of complex interdependence: neither hierarchy nor anarchy prevails, and states really practice self-help' (Haas, 1993, p. 27). In the case of education, coordination takes place around supranational norms to facilitate deeper educational governance. Regimes, such as CARICOM and the Commonwealth arise when states realise that the desired distribution of 'public goods' cannot occur by way of autonomous action. Thus, regimes function by negotiating agreements that deliver collective or private goods, such as education to member states. In this way, regimes can be differentiated based upon their function along a continuum ranging from specific and singleissue, to diffuse and multi-issue (Puchala and Hopkins, 1983). Regime theory recognises that the dynamism that exists at the international level, given different levels of uncertainty, will force nations - big and small - to be more conducive to policy coordination or cooperation (see Patnaik, 1996). While international regime theory is often identified with 'hegemonic stability theory' (Patnaik, 1996), this paper departs from this orthodoxy and suggests that regime theory has the potential to explain the negotiation, coordination, and governance of education from an international politicaleconomic perspective. As such, regime theory provides a framework for us to study the institutional space in which regional governance emerges, and the ensuing scales of educational governance and educational regulation across the national level are both multifaceted and multidimensional. Thus, a regime's legitimacy depends upon the parameters that members negotiate or impose upon themselves. Therefore, regime theory as a conceptual framework allows us to understand CARICOM and the Commonwealth as trans-regional regimes and the trans-regional spaces that they occupy and within which they operate.

\section{The Changing Face of Caribbean Regional and Hemispheric Integration}

CARICOM is legislated by the Conference of Heads of Government of the Caribbean Community (CHGCCs), maintained through councils, congresses, and other bodies, and monitored by the Bureau of Heads. Regimes establish hierarchies of values, emphasising some and discounting others. This is exemplified in the Grand Anse Declaration (CARICOM, 1989), which emphasised the Caribbean Single Market and Economy (CSME), the economic pillar of regionalism, while neglecting the two non- economic pillars of foreign policy coordination and functional cooperation (identified as an integral part of the integration project in the Declaration on Functional Cooperation in 2007). The crusade towards more explicit governance mechanisms to regulate CARICOM, as attempted in the Rose Hall Declaration on Regional Governance and Integrated Development (Caribbean Community Secretariat, 2003), is a standard strategic maneuver by member states to reaffirm statehood while strengthening the regional capability to operate within a global environment. As Jessop (2014) has discussed more broadly, such action by countries does not

cede their claim to sovereignty in the face of growing complex interdependence and [did not] seek to enhance their political capacities by participating in hierarchic coordination mechanisms or devolving some activities to private institutions and actors, [that would] seek to shape and steer these mechanisms through meta-steering practices (p. 20).

The Rose Hall Declaration reaffirms that CARICOM is a community of sovereign states and continues to legitimize principles of 'proportionality' and 'subsidiarity.' The proportionality principle emphasizes that 'institutional arrangements devised for Community action shall not exceed what is necessary to achieve actions' (Lewis, 2006) specified in the Revised Treaty. The principle of subsidiarity, which supports the principle of proportionality, stipulates that regional acts 'would not be pursued in cases where action by the individual Member States is sufficient to achieve the specific goals of the Community' (Lewis, 2006, p. 5). In fact, CARICOM's role has been relegated to that of 'strategic coordination' (Jessop, 2000) in an era defined by 'meta- steering' (constitutional or institutional design) (Jessop, 2000) and the proliferation of new governance mechanisms (mature regionalism) across all of its core pillars (functional cooperation, economic integration, foreign policy coordination and security in 2005).

One of the biggest challenges to regime configuration has been the proliferation of other regional and subregional organisations and issue-specific regimes, such as the World Declaration on Education for All or Dakar Framework for Action and complex regimes, which incorporate more than one regime, such as Millennium Development Goals and Sustainable Development Goals. Historically, in the English-speaking Caribbean, subregionalism in the form of the Organization of Eastern Caribbean States (OECS) was accepted as part of the larger regional project as it did not threaten economic integration. Moreover, as the OECS has a functioning economic union and monetary coordination, it presents an example of how the larger Caribbean integrative project could function. In essence, sub-regionalism has been tolerated since it does not contradict the core principles of Caribbean integration in 
that six of the seven full members of the OECS are also members of the CSM.' In 1994, when all of CARICOM's members agreed to be members of the proposed Free Trade Area of the Americas (FTAA) - which was an extension of the North American Free Trade Agreement (NAFTA) - the future of neoliberalism and the ability of CARICOM countries to be integrated into the global market with the backing of this new trade powerhouse looked great until it was stalled.

Hemispherically, up until 2000, the regional political projects within Latin America and the Caribbean were separate and oriented along cultural, ethno-linguistic, and colonial geographic lines. This changed when Belize joined the Sistema de la Integración Centroamericana (SICA). ${ }^{2}$ In 2010, four years after the CSM formally came on-stream in 12 of 15 CARICOM countries, regional leaders increasingly perceived new 'existential threats' that challenged the economic prosperity, food security, and ecological balance of integration projects (Girvan, n.d.). Guyana and Suriname joined the Union of South American Nations (UNASUR), which combined two existing customs unions, namely the Southern Common Market (MERCOSUR) and the Andean Community of Nations (CAN). In 2011, 13 CARICOM states were among the 33 countries that signed the Declaration of Caracas, creating the Community of Latin American and Caribbean States (CELAC) with its focus on deeper integration. ${ }^{3}$ In 2012, Haiti, Suriname, and St Lucia acceded to the Bolivarian Alliance for the Peoples of Our America (ALBA), a socialist project of which numerous CARICOM members - Antigua and Barbuda, Dominica, St Vincent, and the Grenadines - had long been members. ${ }^{4}$ The adhesion of several more members to ALBA raised questions about the viability of the Caribbean integration project. Additionally, CARICOM countries belong to other regional zones promoting economic cooperation: all are members of the Association of Caribbean States, and nine CARICOM countries belong to the Sistema Económico LatinAmerican y del Caribe (SELA). ${ }^{5}$ Then there are other projects such as PetroCaribe: a Venezuelan subsidized-credit scheme for oil now linked with ALBA, which accounts for 12 of the 15 CARICOM members. ${ }^{6}$

Coupled with this cross-pollination of political projects, new hemispheric initiatives - such as the Pacific Alliance, which links free-trading Chile, Peru, Colombia, and Mexico together - are on the rise, just as other movements are declining. A clear example is the barely functioning ALBA: a vision of Latin American integration that is deteriorating in the aftermath of Hugo Chávez's death. The proliferation of regional institutions in Latin America and the Caribbean does not affect a more integrated region. Instead, it high- lights how economic trading blocs are perceived as inefficient, and governments are trying to keep their hands in all the regional pies, so to speak.

This renewed faith in regionalism is a sign that governments are looking for safe havens in a period of protracted uncertainty and instability. Moreover, the retreat towards the regional level follows the patterns of the 1970s and 1980s that created the Caribbean Basin Economic Recovery Act, which focused on providing traffic reduction and trade benefits. As then, so too now, the changing global environment means that Caribbean regionalism will face its own 'insurgencies' as questions around its legitimacy arise. Among several different factors, there is, in particular, a trinity of forces that are reshaping the region at the present moment. ${ }^{7}$ First, the pendulum of American foreign policy has swung towards Asia, in the form of the Trans-Pacific Partnership (TPP), and now back again with NAFTA (North American Free Trade Agreement) to be replaced with USMCA (United States-Mexico-Canada Agreement) meaning that the Caribbean is no longer seen by the US as having the geostrategic importance it once did. Second, as the USChina trade war wages, China is gradually replacing America as the chief benefactor of the Caribbean in terms of aid and assistance as it continues to expand its influence via state lending, private investment, and outright gifts in the form of new stadia, roads, official buildings, and ports. Simultaneously, more Chinese nationals are working and living in the region. Third, the conditionalities attached to the European Development Fund, now in its 10th cycle, and its linkages to the controversial Economic Partnership Agreement (EPA) call for the abolition of preferential trade rules. The changing face of Caribbean regime configuration is not by choice. Instead, it is responding to a protracted global environment that is now defined by a retreat towards protectionism at the regional level or what has been called the rise of the 'gated global' (Economist, 2013). In the case of CARICOM, this has invited speculation that it is an obsolete regional project. However, considering the broader argument in the paper, the issue is not with CARICOM per se but with how we have sought to theorise it and the lessons for other regional projects.

\section{Lessons for the Commonwealth Project}

From the perspective of educational cooperation driven by regime configuration, there are two clear examples of how CARICOM as a regime has sought to use principles, norms, rules, and decision-making procedures to streamline its functional educational projects. The first has been the reforming of regional institutions of higher education, notably 
the University of the West Indies, which is facing exogenous challenges from the proliferation of other foreign tertiary institutions. Another example, is the establishment of accreditation bodies at the national (National Accrediting Bodies) and regional (Regional Accreditation Mechanism [RAM]) levels to allow skilled labour (artisans, nurses, teachers, university graduates, sportspersons, musicians, managers, technical and supervisory staff, and media workers) to move freely across the 13 countries that comprise the Caribbean Single Market (CSM) established in 2006. From a regime perspective using coordination, CARICOM has ensured that these bodies have worked with the Caribbean Examination Council (CXC) to ensure the mutual recognition and acceptability by other international bodies of educational certification provided across the region at the national level. This has led to the coordination of technical and vocational education and training qualifications across the region under the Regional Occupational Standards in the form the Caribbean Vocational Qualifications (CVQ) which has eight qualifying levels that enable the movement of skilled labour across the region. These are monitored by the Caribbean Association of National Training Agencies (CANTA), through the Regional Coordinating Mechanism for Technical and Vocational Education and Training (RCMTVET). These two examples highlight the complexity of educational cooperation and illuminate that educational cooperation is best used when other institutional mechanisms (economic and political) have failed. In CARICOM's case, its success with cooperation in its functional areas has been a response, beginning in 2007 with the Declaration on Functional Cooperation, which has sought to advance soft power across functional areas after the economic project had reached an impasse.

Thus, educational cooperation in the Commonwealth project should deviate from the orthodoxy of relying on development assistance from international knowledge banks ([IKBs Jones, 2007) such as, the World Bank, the International Monetary Fund, and other United Nations Agencies) and towards modes of coordination or meta-steering where Commonwealth project takes more responsibility for the strategic coordination of the bloc's educational governance agenda with buy-in and streamlining from member states or what has been called 'cooperative transfer' in education (Jules, 2015). As a regime and in striking a balance between intergovernmentalism and supranational actions, Commonwealth coordination of soft educational governance can model its reforms on regulatory instruments, such as the EU's Open Method of Coordination (OMC) model. Today, regimes are using 'self-regulatory strategic coordination' to shepherded educational reforms in the era of what I call 'educational multistakeholderism' where new regimes and institutions arise and coexist alongside two or more classes (civil society, nongovernmental, intergovernmental, businesses, and state) of actors. As such, the grandiloquence in international educational cooperation is no longer rhetorical, and older colonial patterns of cooperation are still prevalent where cooperation in Commonwealth countries is still seen as North-South endeavour rather than one between equals who are fighting against one perceived monster, market fundamentalism. While CARICOM and other Commonwealth countries share similar characteristics, through their shared purpose and design, education cooperation in these regimes should be based on survival as opposed to one driven by dependencia in an era where new modalities of service delivery have emerged. Such a shift is essential given that the discourse in educational cooperation is moving from one of 'partnership,' which grew out of the conditionalities of international knowledge banks and government and universitydriven cooperation to one of multistakeholderism that is motivated by transnational education trends, involving the four modes of trade in education services (cross-border supply, consumption abroad, commercial presence, and presence of natural persons).

Suggesting that the Commonwealth's educational arm should be viewed as an education regime is premised upon the fact that the temporal spaces and geometries of strategic cooperation, technical and financial assistance in education, are changing from one driven by knowledge banks, international institutions, United Nations agencies, (UNESCO, UNDP, ILO, UNICEF, UNHCR), and multilateral and development banks (Caribbean Development Bank, Inter-American Development Bank etc.) to those of 'complex educational regimes' in light of the complex web of institutional density, which has expanded drastically since the 1990s (Jules, 2018). The growing visibility of education at all levels and its place on international agendas implies that new actor or 'educational brokers' ([Jules and Stockdale Jefferson, 2016] philanthropic bodies, manage- ment consultant and private equity firms, and credit rating agencies) are producing, consuming and commodifying the knowledge around educational reforms at the national level. Therefore, one-time vanguards like the Commonwealth risk obsolescence if they do not reform to keep abreast of the sweeping changes that have been brought about by big data and the ensuing emergent intelligent economy (Jules and Salajan, forthcoming).

Regime complex(es) are constituted by several other issue-specific regimes. Regime complex(es) in educational regimes have arisen from a multifaceted "spaghetti bowl's (Bhagwati, 1995) of education governance - resulting from the multiple and concurrent participation by governments in different educational agreements across various levels 
(supranational and global) in today's multistakeholder governance environment' (Jules, 2018, p. 140). We take as a given that Regime Complex(es) are constituted by different types of multistakeholder governance, as Jules (2018) suggests that they 'facilitate educational cooperation and are composed of assemblages from several other regimes, are responsible for governing, steering, and coordinating education governance activities through the use of agreements, treaties, global benchmarks, targets, and indicators' (p. 140). Viewed from this vantage point, the current work of the Commonwealth in education, which has diversified, is jointly managed with the use of resources from governments, business, and civil society. This implies that the power dynamics in educational cooperation are moving away from the former colonial powers of the West and toward a rising Orient. Thus, as the Commonwealth seeks to achieve all 'higher-order' goals in education, to benefit its members, it must recognise the changing institutional and governance landscape. Thus, the current divisions between big and small states, Cold War isolationist notions of statehood, the partnership model (which translates to ownership) of technical assistance, the sector programme model of local ownership, and the top-down North-centric approach to education reform can no longer be the orthodoxy. While the Commonwealth reflects a different type of multilateral collaboration and its educational cooperation infrastructure is advanced (inclusive of the Virtual University for the Small States of the Commonwealth, Commonwealth of Learning, and the Commonwealth Scholarship and Fellowship Plan), it cannot operate as though it is unaware of the global forces that affect its work. This is a concern since cooperative educational priorities have focused on the internal workings of national systems as countries have achieved different global goals around universal primary education and secondary education while the demand for tertiary education outpaces supply across member states. As several scholars have suggested, state size, particularly in the case of the 31 out of 53 members that are small or micro-states, should not be viewed as a 'vulnerability deficit': rather, smallness should be seen as a potential source of strength (Baldacchino, 2012; Jules and Ressler, 2017).

\section{Conclusion}

In short, the Commonwealth project can avoid the fate of CARICOM by reforming and emerging as a leaner and more integrated regime by working with the strength of its member states. A logical step towards this path would be to strengthen and build on its engagement of smallness as a source of strength and an incubator of innovation by leveraging the unique structures, institutions, bureaucracies, and resources that small states bring to bear. In the past, in comparison with other international bodies, the Commonwealth was viewed as a champion of small states and held a competitive advantage as their development partner. Seeing the Commonwealth as a regime allows for the retooling of its normative principles, institutional structures, and legal systems which guide its delivery and operation of education services across its member states. As a community of shared value, this implies that the Commonwealth project will need to provide dedicated investments to change the current climate while mitigating other externalities. Thus, the commonwealth must encourage true compliance. With the rise of the fourth industrial revolution, Commonwealth cooperation in education will confront numerous challenges as its members continue acceding to multiple regional, hemispherical, and global agreements that contradict Commonwealth initiatives and goals while privileging other norms that may conflict with Commonwealth targets. The intelligent economy defined by multistakeholder governance and shaped by regime complex(es) has arrived, and it is transforming the ways we live, play, and educate. As datification increases, artificial intelligence moves from the realm of science fiction to reality, connectivity becomes more pervasive, and governments engage with citizens and consumers alike, these sweeping changes have transformative potential for the cooperative endeavours of CARICOM and the Commonwealth alike.

\section{Notes}

1. While Montserrat is a founding member of CARICOM, it is also a British Overseas Territory and has not been given permission yet to accede to the Revised Treaty of Chaguaramas and participation in the CARICOM Single Market.

2. Central American Integration System.

3. Members of CELAC: Antigua and Barbuda, Bahamas, Barbados, Belize, Dominica, Grenada, Guyana, Jamaica, Saint Lucia, Saint Kitts and Nevis, Saint Vincent and the Grenadines, Suriname, and Trinidad and Tobago.

4. Dominica joined in 2008, and Antigua and Barbuda and Saint Vincent and the Grenadines joined in 2009. 
5. Latin American and the Caribbean Economic System.

6. Barbados, Montserrat, and Trinidad and Tobago are not member of Petrocaribe.

7. These factors are not all-encompassing but are listed here as the new 'existential threats' that the regional project currently faces (see Bishop et al. (2011, p. 50).

8. The 'spaghetti bowl' metaphor was first used by Bhagwati (1995) to conceptualise the overlapping nature of preferential trade agreement between different countries.

\section{References}

Altbach, P. G. and McGill Peterson, P. (2008) America in the world: higher education and the global marketplace, in D. P. Baker and A. W. Wiseman (Eds.), The Worldwide Transformation of Higher Education. Emerald Group Publishing Limited, pp. 313-335.

Baldacchino, G. (2012) Meeting the tests of time: small states in the 21st century, Current Issues in Comparative Education, 15(1), pp. 14-25.

Bhagwati, J. N. (1995) US trade policy: the infatuation with FTAs. Department of Economics, Columbia University. http://doi.org/http://hdl.handle.net/10022/AC:P:15619, accessed 23 May 2019.

Bishop, M. L., Girvan, N., Shaw, T. M., Mike, S., Kirton, R. M., Socbie, M. ... Anatol, M. (2011). Caribbean Regional Integration. Waterloo, ON: The Centre for International Governance Innovation.

Caribbean Community Secretariat. (2003, July) The rose hall declaration on regional governance and integrated development(Rep.). http://www.caricom.org/jsp/communications/meetings_ statements/rose_hall_declaration.jsp?menu=communications accessed 23 May 2019.

CARICOM. (1989) Grand anse declaration and work programme for the advancement of the integration movement. https://caricom.org/communications/view/grand-anse-declaration-and -work-programme-for-the-advancement-of-the-integration-movement accessed 23 May 2019.

Chisholm, L. (2009) Introduction: rhetoric, realities, and reasons, in L. Chisholm and G. SteinerKhamsi (Eds.), South-South Cooperation in Education and Development. Cape Town: HSRC Press, pp. 1-13. (International Perspectives on Education Reform).

Dale, R. (2005) Globalisation, knowledge economy and comparative education, Comparative Education, 41(2), pp. 117-149. doi:10.1080/03050060500150906

Girvan, N. (n.d.) Are Caribbean countries facing existential threats? http://www.normangirvan. info/girvan-existential-threats/, accessed 15 May 2019.

Haas, E. B. (1993) Beware the Slippery Slope: Notes toward the Definition of Justifiable Intervention. (Vol. 42, Policy Papers in International Affairs). Berkeley, CA: University of California.

Hone, K. (2014) Education diplomacy - towards a common understanding. https://norrag. wordpress.com/2014/11/27/education-diplomacy-towards-a-common-understanding/, accessed 23 May 2019.

Jervis, R. (1993) Security regimes, in S. D. Krasner (Ed.), International Regimes. Ithaca, NY: Cornell University Press, pp. 173-190.

Jessop, B. (2000) The crisis of the national spatio-temporal fix and the tendential ecological dominance of globalizing capitalism, International Journal of Urban and Regional Research, 24, pp. 323-360. doi:10.1111/ijur.2000.24.issue-2

Jessop, B. (2014) Hollowing out the 'nation-state' and multi-level governance, in A Handbook of Comparative Social Policy. 2nd ed. Cheltenham: Edward Elgar, pp. 11-26.

Jones, P. W. (2007) World Bank Financing of Education: Lending, Learning and Development. London: Routledge.

Jules, T. D. (2015) Educational exceptionalism in small (and micro) states: cooperative educational transfer and the case of TVET, Research in Comparative and International Education, 10 (2), pp. 202-222. doi:10.1177/1745499915571706 
Jules, T. D. (2016) 'Gated globalization,' regionalism and regional trading agreements: educational diplomacy in an epoch of the post-bureaucratic state, in E. J. Francois, M. B. M. Avoseh and W. Griswold (Eds.), Perspectives in Transnational Higher Education. Rotterdam, The Netherlands: Sense Publishers, pp. 23-37.

Jules, T. D. (2018) Educational regime complexity: nested governance and multistakeholderism in the fourth industrial revolution, in A. W. Wiseman (Ed.), Annual Review of Comparative and International Education 2017. Bingley, UK: Emerald Publishing, pp. 139-158.

Jules, T. D. and Ressler, P. S. (2017) Is "Small” Always Small and "Big" Always Big? Re-Reading Educational Policy and Practice in Small States. Berlin, Germany: Peter Lang.

Jules, T. D., and Sadie Stockdale, J. (2016) The next educational bubble - educational brokers and education governance mechanisms: who governs what!, in T. D. Jules (Ed.), The Global Educational Policy Environment in the Fourth Industrial Revolution: Gated, Regulated and Governed. Bingley, UK: Emerald Publishing, pp. 123-147.

Jules, T. D. and Salajan, F. (forthcoming) The Educational Intelligent Economy: Big Data, Artificial Intelligence, Machine Learning and The Internet of Things in Education. Bingley, UK: Emerald Publishing.

Keohane, R. O. (1983). The demand for international regimes, in S. D. Krasner (Ed.), International Regimes. Ithaca, NY: Cornell University Press, pp. 141-170.

Keohane, R. O. (1984) After Hegemony: Cooperation and Discord in the World Political Economy. Princeton, NJ: Princeton University Press.

Krasner, S. D. (1981) Transforming international regimes: what the third world wants and why, International Studies Quarterly, 25(1), pp. 119-148. doi:10.2307/2600213

Krasner, S. D. (1982) Structural causes and regime consequences: regimes as intervening variables, International Organizations, 36(2), pp. 185-205. doi:10.1017/cbo9780511808760.004

Krasner, S. D. (Ed.) (1983) International Regimes. Ithaca, NY: Cornell University Press.

Lewis, V. A. (2006) Report of the Technical Working Group on the Governance of the Caribbean Community (Rep.). St. Augustine: Republic of Trinidad and Tobago.

McKenzie, P., Horne, R., Dowling, A. and Beavis, A. (2008) Harnessing educational cooperation in the EAS for regional competitiveness and community building. Regional Economic Policy Support Facility (REPSF) II Project No. 07/006. https://research.acer.edu.au/int_ research/1, accessed 23 May 2019.

Morais Silva, M. (2009) South-south cooperation in times of global economic crisis. One-pager No. 76, International Policy Centre for Inclusive Growth. https://ideas.repec.org/p/ipc/opager/76.html, accessed 23 May 2019.

Nye, J. S. (2004) Soft Power: The Means to Success in World Politics. New York, NY: Public Affairs.

Patnaik, J. K. (1996) International political economy and regime analysis: a developing-country perspective, International Studies, 33(2), pp. 155-181. doi:10.1177/0020881796033002002

Peard, I. (1951) Cooperation in education, Pi Lambda Theta Journal, 30(1), pp. 11-15. Creative teaching 17th biennial council. https://www.jstor.org/stable/42916602

Puchala, D. J. and Hopkins, R. F. (1983) International regimes: lessons from inductive analysis, in S. D. Krasner (Ed.), International Regimes. Ithaca, NY: Cornell University Press, pp. 61-92.

Stein, A. A. (1982) Coordination and collaboration: regimes in an anarchic world, International Organization, 36(2), pp. 299-324. doi:10.1017/S0020818300018968

The Economist. (2013, October) World economy - The gated global. https://www.economist. com/special-report/2013/10/10/the-gated-globe, accessed 23 May 2019.

Williams, J. H. (2017) International cooperation for education in developing countries, in G. Noblit (Ed.), Oxford Research Encyclopaedia of Education. Oxford, UK: Oxford University Press, pp. 1-23.

Young, O. (1983) Regime dynamics: the rise and fall of international regimes, in S. D. Krasner (Ed.), International Regimes. Ithaca, NY: Cornell University Press, pp. 115-140. 